\title{
The Effect of Irrigation on the Annual Apical Growth of the12-14 Years Old Seed Plants of Black Saksaul
}

\author{
Daniyar Dosmanbetov ${ }^{1 *}$, Bagila Maisupova², Kurmankul Abaeva, \\ Bulkair Mambetov ${ }^{1}$, Ruslan Akhmetov² \\ 1 Kazakh National Agrarian University, Almaty, Kazakhstan \\ 2 Kazakh Research Institute of Forestry and Agroforestry, Almaty, Kazakhstan \\ * Corresponding author's e-mail: dosmanbetov.d@mail.ru
}

\begin{abstract}
This article discusses the ways of solving the problems of fruiting and increasing the yields, as well as obtaining high-quality standard seeds from promising seed plants of black saksaul (Haloxylon aphyllum (Minkw.) Iljin). It presents the results of studying the effect of irrigation and the use of fertilizers on the annual growth of the apical shoots of saksaul, and the effect of irrigation on the further stability of seed plants fruiting for sustainable seed supply for reproduction of saksaul deserts and forest amelioration of deserts. The morphological description of the soil by profiles has been given, and the effect of irrigation on the soils of the type II forest conditions has been described. This study was aimed at resolving the problem of fruiting frequency, increasing the yield and quality of promising black saksaul seed plants by determining the moisture dynamics in the one-meter thick soil layer under saksaul specimens for determining the methods, norms, and time of irrigating seed plants. Long-term observations show that well-developed specimens of black saksaul have appeared in the last 15-20 years on the roadside in some settlements, e.g., Bakbakty, Bakanas, Akkol, Koktal, Karoy, the motor road in village Kanshengel, Topar, Araltobe, Akzhar in the Almaty area, which passes through natural saksaul plantings and the soil with the formation of layered clay, sandy loam, and crushed stone. On the one hand, this was promoted by the presence of layered and well-aerated roadsides of the bulk roadbed, and on the other hand, by additional wetting from the runoff of precipitation from the asphalt pavement.Naturally, these saksaul plantings growing along the roads alone or in rows give a good yield when fruiting; seed plants may also be identified in these groups.
\end{abstract}

Keywords: Black saksaul, forest growth conditions, soil profile, soil, laboratory analysis, annual apical growth.

\section{INTRODUCTION}

Black saksaul is interesting as a species that not only is distinguished by peculiar ecology, but also has great practical significance in the desert zone. This biologically stable and durable tree species is used to fix moving sands, to protect pastures from wind erosion, to increase forage productivity of the pastures, and to protect animals from frequent winter storms [Faizov, 1980; Abdraimov, 1988; Mambetov et al., 2016].

Since black saksaul reproduces only by seeds, the issues of seed propagation are of great interest. Saksaul plantings perform important soilprotective, environment-improving, sanitary, and hygienic functions [Shamsutdinov, 1984], contribute to the formation of stable and productive pastures, serve as the main base for distantpasture cattle rearing [Mambetov et al., 2017]; they are used for creating artificial pastures [Sychev, 2005], they are the habitat of rare animal species, and preserve the flora.

Representatives of the Haloxylon genus Haloxylon aphyllum and Haloxylon persicum grow on the territory of Kazakhstan and occupy large areas in the Il-Balkhash region.

Many researchers have studied the anatomical structure of the Haloxylon genus [Dosmanbetov et al., 2018; Kabanova, Danchenko, 2017]; among Russian scientists who performed anatomical studies Lee et al. [2013] are noted. To provide a theoretical base for the recommendations 
for restoring the natural ecosystems in the desert areas and ensuring stability of the natural ecosystems, it is necessary to study the anatomy and the structure of green shoots of two species of the Chenopodiaceae family (Haloxylon aphyllum, $\mathrm{H}$. persicum) and to analyze the similarities and differences between the morphometric parameters and the adaptive capacity of the studied taxa.

After massive felling, saksaul plantings recover only within 30-40 years, but they can reach their former state only after a few hundred years. A good harvest of saksaul $(4-5$ points in a 6-point assessment), according to several authors [Maysupova et al., 2016:Mambetov et al., 2016], occurs once in 3-4 years.

However, according to the observations of the authors, in the Southeast of Kazakhstan (in the Southern Balkhash region), a good harvest occurred in 1999 and in 2009, i.e., once in 10 years. This is due to the intensive anthropogenic impact on saksaul plantings and the global warming.

For instance, after 1995, when switching to market relations and searching for the most optimal structure and forms of forestry management, the overwhelming part of the best black saksaul plantations in the Southern Balkhash area turned out to be sparse and weakened, and the average air temperature here increased by more than $1^{\circ} \mathrm{C}$. All this disrupted the existing regularities in the biology of saksaul, and, in addition to increasing the period between years with good fruiting, increased saksaul susceptibility to diseases and pests. In this situation, the main attention was paid to the reproduction of black saksaul as the most common species playing a fundamental role in improving the ecology of the region and at the same time being intensively destroyed.

\section{MATERIALS AND METHODS}

Particular attention was paid to the possibility of choosing forest areas with additional source of moisture, including concentration of the precipitation runoff or snow trails. Such areas may be found along the edges of saksaul plantations, and on the north side of the sandy ridges that cross the ancient alluvial plain at certain distance. Initially, these areas were visible by lusher grass vegetation. In this regard, according to the Drude scale of abundance, the projective cover of the soil by grass vegetation, the composition of its abundance by the species, and grass vegetation height expressed in $\mathrm{cm}$ were described. After that, three soil boreholes 1-2 $\mathrm{m}$ deep were made along the line perpendicular from the sandy ridges in the centers of glades at the distance of $10 \mathrm{~m}$. The time of making wells was the first half of April. They were intended for determining the depth of soil wetting and identifying the contours of the area with more favorable water-physical and, therefore, forest growth conditions for saksaul forests.

Roughly, the contours of three areas with favorable water-physical conditions were determined annually. For this purpose, $100-150$ soil boreholes 1-2 m deep were made. Watering of the experimental seed plants was made in groups of 6-8 and 12-14 years old seed plants along a single radial furrow $1 \mathrm{~m}$ from the trunk, in groups of 21-24 and 40 or more years old - in two circular furrows at the distance of 1 and $2 \mathrm{~m}$ from the root neck of the seed plants. The moisture content in the soil was determined using the thermal gravimetric method with the aim of studying its dynamics and the time of seed plants watering.

In the studies aimed at refining the types of forest growth conditions, works of Pashkovsky [1989] and three groups of types of saksaul were taken as the base:

1. Plain;

2. Low hills, sand ridges, hillocks and their slopes; and

3. High sand ridges, hillocks and their slopes.

During the research, the authors studied the maps of forest stands of state forestry institutions, and the routes were determined. Along the routes with the above three groups of saksaul forest types, the growth conditions of the plantings were described and the taxation characteristics of saksaul forests were determined. For this purpose, trial plots were laid with coverage of lowdensity $(0.3-0.4)$, medium-density $(0.5-0.6)$, and high-density $(0.7-0.8)$ plantings in all three groups of forest types. With that, the route number, its direction, the date of laying a temporary trial plot and its coordinates were documented. Each trial plot had to have at least 100 accounting specimens of saksaul.

In addition, the following was described for each trial plot: forest type, geographical location, terrain, surrounding grounds, grass cover, including the overall projected coverage of the soil in percent, grass species, abundance by Drude, and height in centimeters. 
The groundwater level (further referred to as GWL) was determined by the nearest wells; the soils were studied in accordance with the guidelines.

With that, the authors determined the thickness of genetic horizons, humidity, color, structure, consistence, mechanical composition, presence of roots, boiling from $10 \% \mathrm{HCl}$, inclusions, neoformations, and transition to the next horizon.

From the most typical soil cross-sections, soil samples were taken with the weight no more than $0.5 \mathrm{~kg}$ each. These samples were analyzed with the determination of the chemical composition of the aqueous extract.

Based on the Guidelines for Soils Classification and Diagnostics and the results of the aqueous extract analysis, the degree and the chemism of soil salinity were determined. Special attention was paid to the presence of alkali, chloride, and sodium salinification.

The chemical composition of the agrohydrological properties of the soils and the content of mobile nutrients in the soils in this region were determined by the existing reference books, and the degree of soils salinification and coils composition - based on the analysis of the aqueous extract.

The hydrological conditions of the soil were studied in accordance with the existing methods. Soil cross-sections were made in the most typical locations or in typical groups of soils, the morphological horizons of the soil were described, and soil samples were taken for laboratory analysis. Based on the morphological description of the soil horizons and the chemical composition of the soils, the composition and salinity of soils were determined, and the lowest soil moisture capacity was identified.

Watering of the experimental seed plants was made in groups of 12-14-years-old seed plants in a single circular furrow located at the distance of $1 \mathrm{~m}$ from the trunk. The moisture content in the soil was determined using the thermal gravimetric method with the aim of studying its dynamics and the time of seed plants watering. The types and norms of mineral fertilizers were determined by the presence of hydrolysable nitrogen, mobile forms of phosphorus and potassium. The 12-14-years-old seed plants were irrigated with 160 and 80 liters per tree three times during the vegetation period. The 12-14-years-old seed plants grew in long-unused gardens on loamy soil.

\section{RESULTS AND DISCUSSION}

The studies were performed in territory of the Municipal Public Utilities Institution Bakanassk Forestry in the Almaty region (Fig. 1).

In recent years, cases of damage to saksaul forests by powdery mildew, gall midges, or turquoise psylla have become increasingly common. Gall midges are an isolated group of small dipterans adapted to the desert living conditions.

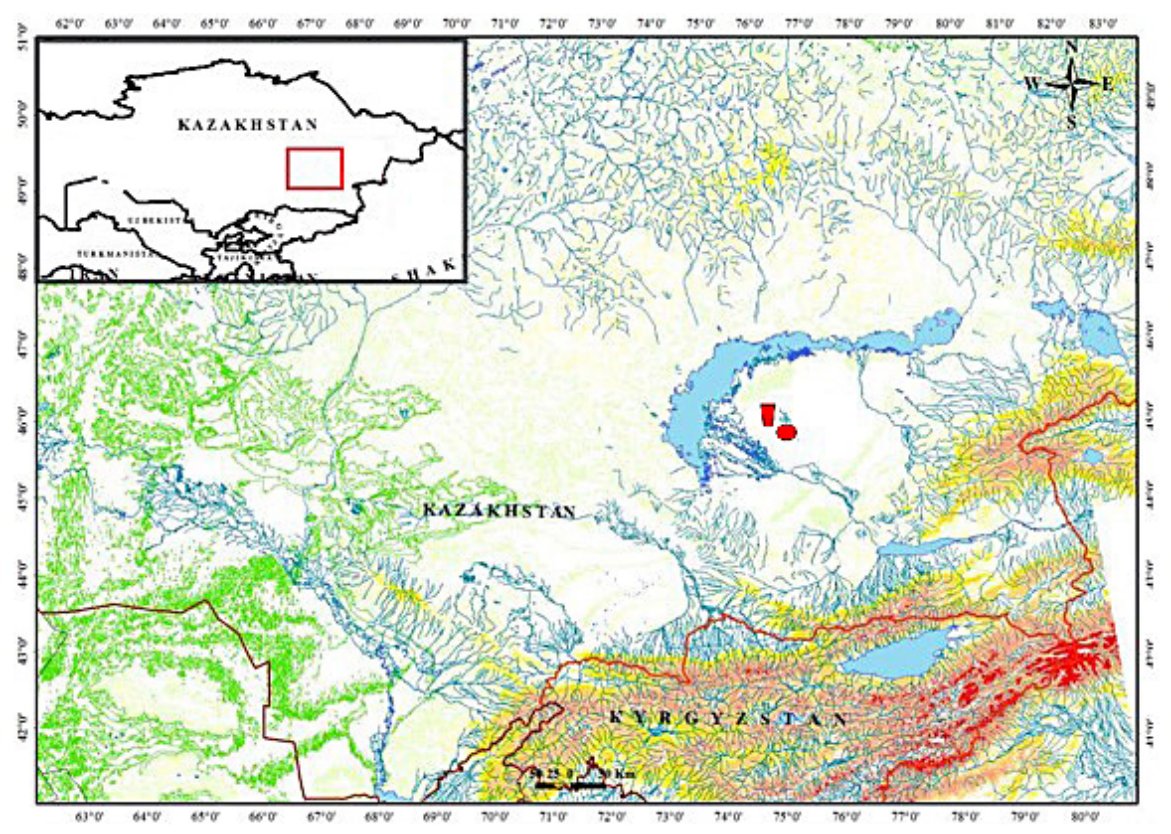

Figure 1. The schematic map of the research works location 
Each species of gall midges is strictly monophagous, and develops on certain parts of the plants and causes formation of specific cockles. Adult specimens do not feed, and live only from a few hours to two or three days. They spread mainly passively, by air currents. Psylla develop in two generations a year, and some - in one generation. Their lifestyle is closely associated with the biology of fodder plants. However, even on this unfavorable background, on well-aerated and additionally humidified soils, there are single specimens and small plantations that bring fruit well and systematically, without or with few diseases and pests. First of all, these include selfseeded saksaul along the roadsides of the highways that pass through saksaul plantings, in particular, these are highways from settlement Bakbakty - settlement Bakanas - settlement Akkol - settlement Koktal - settlement Karoy, roads settlement Konshengil - settlement Topar, and settlement Araltobe - settlement Akzhar. Here within the last 15-20 years, on the road side of the highway, where the soils contain formations of layered clay, sandy loam, and crushed stone, kind of alley plantings or single well-developed specimens of black saksaul appeared. On the one hand, this was promoted by the presence of layered and well-aerated roadsides of the bulk roadbed, and on the other hand, by additional wetting from the runoff of precipitation from the asphalt pavement.

It was also repeatedly noted that small wellfruiting plantings appeared in harvestless years on the light soils with high groundwater level $(2-3 \mathrm{~m})$. Therefore, two important factors for increasing the fruiting of saksaul were identified: 1 - the presence of loose layered soils, and 2 - additional moistening of the seed plants.

The soils were morphologically described by the cross-section P-5A-18 on the loamy soils of long-unused gardens. The description is provided below.

The tables show the results of laboratory analysis of the mechanical composition of soils under 12-14-years-old black saksaul seed plants and water extract from the loamy soil of long-unused gardens (type II), as well as the effect of irrigation on an annual apical growth of 12-14-years-old seed plants of black saksaul.

The results of the laboratory analysis of the mechanical composition of these soils are shown in Table 1.

The data on the soil mechanical composition under 12-14-years-old saksaul seed plants shown in Table 1 correspond to their morphology. Light loamy on the surface, these soils in the middle part of the cross-section become thick and heavy loamy. Their chemical composition is shown in Table 2.

Table 2 shows that these soils are medium alkaline on the surface $(\mathrm{P}=8.33)$ and strongly alkaline in the lower part of the profile $(\mathrm{P}=9.05)$; they are carbonate $\left(\mathrm{CO}_{2}=5.79-6.81\right)$, but not saline. Salts content in the dry residue amounts to $0.165-0.259 \%$. On light hydromorphic soils without visible signs of depression, black saksaul can withstand salinification up to $2.5 \%$ by solid residue.

The growth of 12-14-years-old saksaul seed plants characterized by annual apical growth of the shoots is shown in Table 3.

As follows from Table 3, irrigation of 1-14-years-old seed plants with the norm of 1601 per tree makes the apical shoot growth significantly higher $(43.4 \pm 0.4 \mathrm{~cm})$ than irrigation with the norm of 801 per tree $(33.6 \pm 0.4)$.

Black saksaul forests are an integral component of the psammophytic deserts on ridge-hilly sands. They mostly occupy the depressions between the hillocks, which are, in turn, occupied by white saksaul forests.

In the structure of phytomass, the share of underground organs of black saksaul forests is up to $48 \%$. The share of green parts is about $10 \%$. From these relations it follows that in these formations, the lignified aboveground parts are very important. The productivity of black saksaul forests is almost four times higher than that of white

Table 1. The results of the laboratory analysis of the mechanical composition of the soils under 12-14-years-old seed plants of black saksaul

\begin{tabular}{|c|c|c|c|c|c|c|c|c|c|}
\hline $\begin{array}{c}\text { Cross- } \\
\text { section }\end{array}$ & $\begin{array}{c}\text { Horizon, } \\
\text { No. }\end{array}$ & \multicolumn{6}{|c|}{ The number of fractions to dry soil, \% } & \multicolumn{2}{c|}{$\begin{array}{c}\text { The sum of } \\
\text { fractions, \% }\end{array}$} \\
\cline { 3 - 10 } & & $1.00-0.25$ & $0.25-0.05$ & $0.05-0.01$ & $0.01-0.005$ & $0.005-0.001$ & $<0.001$ & $<0.01$ & $<0.01$ \\
\hline P-5A- & $10-20$ & 0.11 & 47.85 & 29.25 & 7.03 & 11.24 & 4.52 & 22.79 & 77.21 \\
18 & $50-60$ & 0.07 & 31.49 & 10.59 & 12.16 & 25.57 & 20.12 & 57.85 & 42.15 \\
& $90-100$ & 2.40 & 49.08 & 18.95 & 7.59 & 9.62 & 12.36 & 29.57 & 70.43 \\
\hline
\end{tabular}


Table 2. The results of laboratory analysis of the water extract of loamy soils under 12-14-years-old saksaul seed plants

\begin{tabular}{|c|c|c|c|c|c|c|c|c|c|c|c|c|c|c|c|c|}
\hline \multirow{2}{*}{$\begin{array}{c}\text { Cross- } \\
\text { section } \\
\text { No. }\end{array}$} & \multirow{2}{*}{$\begin{array}{l}\text { Horizon, } \\
\mathrm{cm}\end{array}$} & \multirow{2}{*}{$\mathrm{pH}$} & \multicolumn{2}{|c|}{$\begin{array}{l}\text { Mg-equivalent per } \\
100 \mathrm{~g} \text { of soil }\end{array}$} & \multicolumn{2}{|c|}{ Content in \% } & \multicolumn{8}{|c|}{$\begin{array}{c}\text { Mg-equivalent per } 100 \mathrm{~g} \text { of soil } \\
\% \text { to dry soil }\end{array}$} & \multirow{2}{*}{ 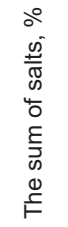 } & \multirow{2}{*}{ 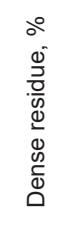 } \\
\hline & & & $\begin{array}{c}\mathrm{Na}^{+} \\
\text {exchange }\end{array}$ & $\begin{array}{c}\text { Exchange } \\
\text { capacity, } \\
\%\end{array}$ & $\mathrm{CO}_{2}$ & $\begin{array}{c}\mathrm{SO}_{4} \\
\text { gypsum }\end{array}$ & $\mathrm{CO}_{3}{ }^{2}$ & $\mathrm{HCO}_{3}$ & $\mathrm{Cl}$ & $\mathrm{SO}_{4}{ }^{2}$ & $\mathrm{Ca}_{+}{ }^{2}$ & $\mathrm{Mg}_{+}{ }^{2}$ & $\mathrm{Na}^{+}$ & $\mathrm{K}^{+}$ & & \\
\hline \multirow{3}{*}{ P-5A-18 } & $10-20$ & 8.33 & 4.04 & 14.0 & 5.79 & 1.56 & - & $\frac{0.72}{0.04}$ & $\frac{0.40}{0.01}$ & $\frac{1.36}{0.06}$ & $\frac{0.50}{0.01}$ & $\frac{1.50}{0.01}$ & $\underline{0.33}$ & $\underline{0.15}$ & 0.16 & 0.17 \\
\hline & $50-60$ & 8.40 & 0.52 & 18.8 & 6.02 & 1.40 & - & $\frac{0.60}{0.03}$ & $\frac{0.50}{0.01}$ & $\frac{2.79}{0.13}$ & $\frac{1.50}{0.03}$ & $\frac{1.50}{0.01}$ & $\frac{0.76}{0.018}$ & $\frac{0.13}{0.005}$ & 0.25 & 0.20 \\
\hline & $90-100$ & 9.05 & 6.38 & 22.0 & 6.81 & 1.33 & - & $\frac{0.68}{0.04}$ & $\frac{0.20}{0.00}$ & $\frac{2.51}{0.12}$ & $\frac{1.20}{0.02}$ & $\frac{1.60}{0.01}$ & $\underline{0.54}$ & $\underline{0.04}$ & 0.22 & 0.23 \\
\hline
\end{tabular}

saksaul forests $(6.7 \mathrm{t} / \mathrm{ha} /$ year). It is mainly formed due to the growth of the underground organs. In relation to the phytomass, the productivity is more than $50 \%$.

The productivity of forest stands is influenced by a number of factors. According to Antanaitis, et al. [1986], the age dynamics of taxation indicators is influenced by such factors as various growing conditions; the peculiarities of tree vegetation biology, species in the forest stand; the conditions in which the forest was formed; the genetic characteristics of specimens, the age structure of the population, their age; the density of the forest stand; the territorial structure of the population; the terrain; the occupied niche of the forest stand; the degree of clutter of the forest; various degrees of environmental pollution; exogenous factors (climatic, natural disasters); geographical position, altitude above the sea level; and the anthropogenic changes.

In the studies of Lear et al. [1974], all factors that influence and determine the growth and the productivity of the forest stand are divided into three groups: the influence of time, the influence of the external environment, and the hereditary qualities of the specimens, which make up a totality. At present, taking into account the factors of hereditary features of every tree and the influence of external environmental conditions is a rather difficult task in determining the dynamics of the forest stand growth; therefore, these criteria are not taken into account.

There is a method of creating plantations of black saksaul that includes suppression of the competing vegetation, soil tillage in $1.5 \mathrm{~m}$ wide bands, leveling the soil surface in bands, scarification of black saksaul seeds, seeding them to the depth of $0.5-1.0 \mathrm{~cm}$, harrowing after seeding, rolling and mulching the top layer, and care and formation of plantations with the density of 900 $-1,200$ plants per 1 ha. The disadvantages of this method include the unacceptably long period (912 years) of obtaining seed material after sowing black saksaul seeds on improved or newly created pastures [Shamsutdinov, 1975].

In arid regions, deserts and semi-deserts are likely to respond to global climatic changes in the geomorphological, the hydrological, the biological, and the biogeochemical aspects [Lioubimtseva et al., 1998]. It was also predicted that arid regions were the most sensitive ecosystems to the global warming, and their responses were most difficult to predict [Lioubimtseva, Cole, 2006; Smith et al., 2000].

The presence of water is a key factor affecting the plant growth, the structure, and the composition of plant communities in arid and semi-arid ecosystems [Le Houerou et al., 1988; Miranda et al., 2009; Robertson et al., 2009; Sala et al., 1988; Schwinning et al., 2004; Yahdjian, Sala, 2006].

Table 3. The effect of irrigating 12-14-years-old saksaul seed plants with 1601 and 801 per tree on the apical annual growth of saksaul

\begin{tabular}{|c|c|c|c|c|c|}
\hline $\begin{array}{c}\text { The age of seed } \\
\text { plants, years }\end{array}$ & $\begin{array}{c}\text { The type of forest } \\
\text { growth conditions }\end{array}$ & $\begin{array}{c}\text { Irrigation norm per } \\
\text { 1 seed tree, I }\end{array}$ & $\begin{array}{c}\text { Annual apical } \\
\text { growth, } \mathrm{cm}\end{array}$ & $\begin{array}{c}\text { Differences } \\
\text { between the } \\
\text { variants, cm }\end{array}$ & $\begin{array}{c}\text { Significance of } \\
\text { differences }\end{array}$ \\
\hline $12-14$ & $\begin{array}{c}\text { Type II (loamy } \\
\text { on long-unused } \\
\text { gardens) }\end{array}$ & 160 & $43.4 \pm 0.4$ & & 17.5 \\
\hline
\end{tabular}


However, there is a global limit to the net primary productivity of land ecosystems [Le Bauer, Treseder, 2008; Vitousek, Howarth, 1991], including desert ecosystems [Hall et al., 2011; Hooper, Johnson, 1999; Krueger-Mangold et al., 2004; Yahdjian et al., 2011]. In addition, there were reports about the relationship between the effect of the water and adding nitrogen on the growth of desert plants, the structure, and the composition of ecosystem communities [Fan et al., 2013;Ladwig et al., 2012; Schmiedel et al., 2012].

Snowfall is a special form of precipitation, and its melting may feed the water in the soil and promote the growth and development of the plants [Wang et al., 2006]. Snow accumulation and removal is currently influenced by the global warming, which significantly accelerates snow melting [Dye, 2002; Rikiishi et al., 2004]. This change may lead to an earlier beginning of the vegetation season [Shabanov et al., 2002].

In arid and semi-arid ecosystems, plants' behavior is limited by water and nitrogen supply [Zhang, Zak, 1998]. However, the data also show that productivity is not directly dependent on the water availability [Gutierrez, Whitford, 1987].

It has been found that the genetic quality of the seeds of Haloxylon aphyllum was not associated with the toxic effects of salt but with the deficit of available water, which is formed on the background of the arid climate and the deep groundwater level, which is typical for sandy soils in the lowland and upland areas of the desert, or the high salt content on solonetzes [Shuyskaya et al., 2012]. Consequently, in terms of the deficiency of available water, the stressful conditions for $\mathrm{H}$. aphyllum are soils with weak and strong salinification, whereas good living conditions will be the soil that contains $1.85-1.93 \%$ of water-soluble salts in the $1 \mathrm{~m}$ thick layer [Shamsutdinov, Shirinskaya, 1963].

\section{CONCLUSION}

Thus, according to the studies performed in black-saksaul forests of the Southern Balkhash area, the following conclusions can be drawn:

1. The used norms of irrigation into circular furrows on the best loose-layered soils have made it possible to ensure the optimal level of moisture, that is, not lower than $40 \%$ of the norm for more than 15-23 days in the one-meter layer under $12-14$ years old seed plants.
2. On heavy soils, the optimum moisture level is kept for no more than 15 days only in the $0-60 \mathrm{~cm}$ thick soil layer.

Given the age of the seed plant, the soil conditions, the depth of soil wetting, and the duration of soil moisture preservation, the following norms for watering black saksaul are recommended:

- for 12-14 years old seed plants - 1601 per tree, into a single-ring furrow; and

- given the recommended norms, it is suggested to water the seed plants on light layered soils 3-4 times, and on heavy soils $-5-6$ times per growing season.

In addition, the promising developments on the irrigation norms will be used in the future in a complex for obtaining seed material, mainly from superior saksaul trees, initial check of their offspring in a nursery, followed by the use of the best offspring for laying seed plantations and raising the level of saksaul reproduction in Kazakhstan.

\section{REFERENCES}

1. Abdraimov S.Y. 1988. Aridnye pastbishcha Kazakhstana [Arid pastures of Kazakhstan]. AlmaAta, 140 p.

2. Antanaitis V.V., Tyabera A.P., Shapyatene Y.A. 1986. Laws, regularities of forest stands growth and structure. Kaunas: LitSHa, 158 p.

3. Dosmanbetov D., Mambetov B., Baisupova B.D., Bukeikhanov A., Kelgenbayev N., Dukenov Z. 2018. Issledovanie kornevykh sistem saksaula chernogo $\mathrm{v}$ raznykh vozrastnykh grupp [Studying the root systems of black saksaul in various age groups]. Izdenister, natijeler. Research and results, 1(77), 165-169.

4. Dye D.G. 2002. Variability and trends in the annual snow cover cycle in Northern Hemisphere land areas, 1972-2000. Hydrol Process, 16, 3065-3077

5. Faizov K.S. 1980. Pochvy pustynnoi zony Kazakhstana [Soils of the desert zone of Kazakhstan]. Alma-Ata, $133 \mathrm{p}$.

6. Fan L.L., Li Y., Tang L.S., Ma J. 2013. Combined effects of snow depth and nitrogen addition on ephemeral growth at the southern edge of the Gurbantunggut Desert, China. J. Arid. Land, 5, 500-510.

7. Gutierrez J.R., Whitford W.G. 1987. Chihuanhuan Desert Annuals. Importance of water and nitrogen. Ecology, 68, 2032-2045.

8. Hall S.J., Sponseller R.A., Grimm N.B., Huber D., Kaye J.P., Clark C., Collins S.L. 2011. Ecosystem response to nutrient enrichment a cross an urban 
air she din the Sonoran Desert. Ecol. Appl., 21, 640-660.

9. Hooper D.U., Johnson L. 1999. Nitrogen limitation in dry land ecosystems: responses to geographical and temporal variation in precipitation. Biogeochemistry, 46, 247-293.

10. Kabanova S. A., Danchenko M. A. 2017. Lesovodstvennye tekhnologii sozdaniya ustoichivykh lesnykh kultur v Kazakhstane [Forestry technologies for creating sustainable forest crops in Kazakhstan]. Kokshetau, 200 p.

11. Krueger-Mangold J., Sheley R., Engel R., Jacobsen J., Svejcar T., Zabinski C. 2004.Identification of the limiting resource within a semi-arid plant association. J. Arid. Environ. 58, 309-320.

12. Ladwig L.M., Collins S.L., Swann A.L., Xia Y., Allen M.F., Allen E.B. 2012. Above-and belowground responses to nitrogen addition in a Chihuahuan Desert grassland. Oecologia, 169, 177-185.

13. Le Bauer D.S., Treseder K.K. 2008. Nitrogen limitation of net primary productivity in terrestrial ecosystems is globally distributed. Ecology, 89, 371-379.

14. Le Houerou H.N., Bingham R.L., Skerbek W. 1988. Relationship between the variability of primary production and the variability of annual precipitation in world arid lands. J. Arid Environ., 15, 1-18.

15. Lear X., Polster G., Fidder G.-I. 1974. Fiziologiya drevesnykh rastenii [The physiology of woody plants]. Moscow: Forest industry, $424 \mathrm{p}$.

16. Lee E.V., Shuyskaya E.V., Matyunina T.E., Toderich K.N. 2013. Sopryazhennost razvitiya reproduktivnykh struktur Haloxylon aphyllum (Minkw.) Iljin po gradientu zasoleniya pochvy [Synchronism in the development of reproductive structures of Haloxylon aphyllum (Minkw.) Iljin by the gradient of soil salinity]. Arid ecosystems, 19(2 (55)), 21-28.

17. Lioubimtseva E., Cole R. 2006. Uncertainties of climate change in Arid environments of Central Asia. Rev. Fish. Sci., 14 (1-2), 29-49.

18. Lioubimtseva E., Simon B., Faure H., Faure-Denard L., Adams J. 1998. Impacts of climatic change on carbon storage in the Sahara-Gobi desert belt since the Last Glacial Maximum. Global Planet Change, 16-17, 95-105.

19. Mambetov B.T., Maisupova B.D., Bukeikhanov A.N. 2016. Borba s opustynivaniem: Problemy sokhraneniya i vosstanovleniya saksaulovykh lesov Kazakhstana [Fighting desertification: Problems of preservation and restoration of saksaul forests of Kazakhstan]. 85th Anniversary of the creation of the All-Russian Scientific Research Agroforestry Institute: materials of an International scientific-practical Conference. Volgograd, 155-160.

20. Mambetov B., Maysupova B. D., Bukeikhanov A., Dosmanbetov D., Kelgenbaev N. 2016. Rezultaty obsledovaniya sozdannykh lesomeliorativnykh nasazhdenii na osushennom dne Aralskogo morya (ODAM) [The results of studying the created agroforestry plantings on the drained bottom of the Aral sea (DBAS)]. Republican Scientific-Practical Conference dedicated to the 20th anniversary of the Il-Alatau SNNP. Almaty, 29-31.

21. Mambetov B., Maysupova B. D., Dosmanbetov D., Bukeikhanov A., Kelgenbaev N., Dukenov Z. 2017. Pastbishchnye lesnye nasazhdeniya peschanykh zemlyakh Kazakhstana [Pasture and forest plantations on sandy lands of Kazakhstan]. "Forest science of Kazakhstan: achievements, problems, and development prospects", dedicated to the 60th anniversary of the foundation of KazNIIILHA: Materials of an International scientific-practical Conference. Schuchinsk, 249-253.

22. Maysupova B.D., Mambetov B.T., Bukeikhanov A.N., Dosmanbetov D.A., Kelgenbaev N.S. 2016. Rezultaty obsledovaniya sozdannykh lesomeliorativnykh nasazhdenii na osushennom dne Aralskogo morya (ODAM) [The results of studying the created by agroforestry plantings on the drained bottom of the Aral sea (DBAS)]. International scientific journal "Science and Peace", 3 (31), 104-106.

23. Miranda J.D., Padilla F.M., Lazaro R., Pugnaire F.I. 2009. Do changes in rainfall patterns affect semiarid annual plant communities? J.Veg.Sci., 20, 269-276.

24. Pashkovsky K.A. 1989. Opyt poseva saksaula v Kazakhstane [The experience of planting saksaul in Kazakhstan]. Alma-Ata, 23 p.

25. Rikiishi K., Hashiya E., Imai M. 2004. Linear trends of the length of snow-cover season in the Northern Hemisphere as observed by the satellites in the period 1972-2000. Ann Glaciol, 38, 229-237.

26. Robertson T.R., Bell C.W., Zak J.C., Tissue D.T. 2009. Precipitation timing and magnitude differentially affect aboveground annual net primary productivity in three perennial species in a Chihuahuan Desert grassland. NewPhytol., 181, 230-242.

27. Sala O.E., Parton W.J., Joyce L.A. Lauenroth W.K. 1988. Primary production of the central grass land region of the United-States. Ecology, 69, 40-45.

28. Schmiedel U., Dengler J., Etzold S. 2012. Vegetation dynamics of endemic rich quartz fields in the Succulent Karoo, South Africa, in response to recent climatic trends. J. Veg. Sci., 23, 292-303.

29. Schwinning S., Sala O.E., Loik M.E., Ehleringer J.R. 2004. Thresholds, memory, and sea-sonality: understanding pulse dynamics in arid/semi-arid ecosystems. Oecologia, 141,191-193.

30. Shabanov N.V, Zhou L.M, Knyazikhin Y., Myneni R.B, Tucker C.J. 2002. Analysis of inter annual changes in northern vegetation activity observed in AVHRR data from 1981 to 1994. IEEE Trans Geosci Remote Sens, 40, 115-130 
31. Shamsutdinov Z.S. 1975. Sozdanie dolgoletnikh pastbishch v aridnoi zone Srednei Azii [Creating perennial pastures in the arid zone of Central Asia]. Tashkent, $176 \mathrm{p}$.

32. Shamsutdinov Z.S. 1984. Nauchnye osnovy i metody sozdaniya pastbishchnykh ekosistem v aridnoi zone [Scientific bases and methods of creating grazing ecosystems in the arid zone ]. Resources of the biosphere in the deserts of Central Asia and Kazakhstan. Moscow, 161-170.

33. Shamsutdinov Z. S., Shirinskaya V. N. 1963. Vliyanie zasolennosti pochvy na rost chernogo saksaula $\mathrm{v}$ usloviyakh kultury [The effect of soil salinity on the growth of black saksaul in the conditions of the culture]. Proceedings of the All-Russia Research Institute of Horse Breeding (VNIIK), 13, 313-322.

34. Shuyskaya E.V., Gismatullina L.G., Toderich K.N., Voronin P.Y., Soldatova N.V. 2012. Geneticheskaya differentsiatsiya Haloxylon aphyllum (Chenopodiaceae) po gradientu zasoleniya pochvy v pustyne Kyzylkum [Genetic differentiation of Haloxylon aphyllum (Chenopodiaceae) by the gradient of soil salinification in the Kyzyl Kum desert]. Ecology, 2, 284-289.

35. Smith S.D., Huxman T.E., Zitzer S.F., Charlet T.N., Housman D.C., Coleman J.S., Fenstermaker L.K., Seemann J.R., Nowak R.S. 2000. Elevated CO2 increases produc-tivity and invasive species success in an arid ecosystem. Nature, 408, 79-82.
36. Sychev A.A. 2005. Itogi i perspektivy lesovyrashchivaniya $\mathrm{v}$ zone proizrastaniya saksaulovykh lesov Respubliki [Results and perspectives of forest regeneration in the growing zone of saksaul forests in the Republic]. Actual problems of forestry and landscaping in Kazakhstan. Materials of the international scientific-practical conference "Forest Reproduction, Afforestation, Landscape Architecture and Greening of the Astana City: State, Problems, and Perspectives". Almaty, 85-90.

37. Vitousek P.M., Howarth R.W. 1991. Nitrogen limitation on Land and in the Sea. How can it Occur? Biogeochemistry, 13, 87-115.

38. Wang X.Q., Jiang J., Wang Y.C., Luo W.L., Song C.W., Chen J.Y. 2006. Responses of ephemeral plant germination and growth to water and heat conditions in the south-earn part of Gurbantunggut Desert. Chin. Sci. Bull., 51, 110-116.

39. Yahdjian L., Gherardi L., Sala O. 2011. Nitrogen limitation in arid-sub humid ecosystems: a metaanalysis of fertilization studies. J. Arid Environ., 75, 675-680.

40. Yahdjian L., Sala O.E. 2006. Vegetation structure constrains primary production response to water availability in the Patagonian steppe. Ecology, 87, 952-962.

41. Zhang Q.H., Zak J.C. 1998. Effects of water and nitrogen amendment on Soil Microbial Biomass and fine root production in a Semi-Arid. Environment in West Texas. Soil Biol. Biochem., 30, 39-45. 